\title{
Up-Dating Lysistrata
}

\author{
Sandy Frances Duncan
}

\section{Lysistrata mis à jour}

Je l'ai rencontré en attendant le traversier de Gabriola. Habillée en longue robe safran et portant des sandales, elle avait l'air étrangère et elle avait froid. Elle m'a dit que son nom était Lysistrata mais cela m'a pris du temps pours me rendre compte qu'elle était vraiment l'héroine de la comédie d'Aristophane. Cela m'a pris encore plus longtemps de me souvenir que nous avions été ensemble déjà une fois, à Lyons, en France. Nous y avions été brûlées comme sorcière, en 1492. Se souvenir, c'est douloureux.

Je l'invite chez moi, et durant plusieurs jours on discute de la lutte des femmes, depuis la nuit des temps jusqu'à aujourd'hui. La situation ne s'est pas beaucoup améliorée depuis 550 av.J.C. J'incite Lys à en faire un discours pour la journée internationale des femmes. Je croyais qu'elle serait d'accord. Je suggère comme sujet celui du droit à l'avortement, et je lui explique ce qui s'est récemment passé dans cette lutte. Elle est d'avis que nous suivons la mauvaise stratégie. Et j'aiainsi droit à tout un plaidoyer.

Pourquoi aller chercher nos droits auprès des hommes m'a-t-elle demandé? Les femmes devraient se souvenir comment faire un avortement lorsque c'est nécessaire. Si les mâles ne veulent pas que nous le fassions et bien je t'avertis que nous serons en état de guerre. Se débattre sur la place publique c'est perdre du temps. Oui, envoyez les femmes auprès du monde masculin, mais seulement pour se renseigner sur ce qui s'y passe. Un peu d'espionnage, pourquoi pas? Les femmes doivent être les prêtresses qui enseignent aux jeunes directement. Lysistrata suggère également que l'on fasse une grève tout comme celle de l'époque classique en Grèce.

Elle reste encore chez moi, mais à la dernière minute elle a refusé de prononcer ce discours pour le 8 mars. C'est donc moi qui vous présente ses idées. Ah, au fait elle viendra me chercher au traversier... 
I bumped into her on Wharf street in front of the chocolate shop. She was standing there, blinking bemusedly at the parking lot below the Coast Bastion, not a prepossessing sight. I thought at first she was a tourist or on her way to a costume ball because of her clothes: a long flowing saffron dress, intricate gold and green belt from which dangled a small bag, and sandals. February has become our coldest month; snow two years in a row. Some Lotusland. Maybe that nickname misled her. At any rate, her toes glowed a sore pink and she was shivering.

"May I help you?" I asked.

"Oh, indeed!" She grasped my arm. "I'm not oriented. It's all confusing."

"And cold," I added, thinking tourist. "Where are you staying?"

"I don't know yet." She folded her arms across her chest as if hugging her last warmth. A small, solid woman, maybe five feet, goldishgreying hair caught back in a bun, brown eyes with laugh lines - an interesting woman, and familiar in the way some people instantly are. I'd just missed the ferry to Gabriola and had an hour to wait; I led her across Commercial street to the closest restaurant, settled us and ordered coffee and greek salad.

"Where are you from?" I asked in my be-nice-to-tourists tone.

"Well - " She looked startled, then discomfitted and embarrassed. "It depends."

"How long are you staying?"

"Well, that depends too." I thought amnesia? but she smiled warily and added, "My name's Lysistrata."

Women change their names all the time now. Perhaps she was a Mary Smith who'd re-named herself. It's what I want to do, but haven't yet, so I said, "I'm Sandy."

She drank her coffee and ate most of the salad and seemed to be warming up. We kept catching each other's eyes and smiling but the longer we said nothing the less I could think of to say. From the way she stroked the handle of her cup, I thought maybe she was stuck too, but then she mumbled, "May I ask you a question?"I nodded. "Where am I actually?"

"Nanaimo."

"Nanaimo." She tried the sounds. "This might sound silly, but where is Nanaimo?" She had a faint accent - Brooklyn or New Jersey perhaps.

"East coast of Vancouver Island, British Columbia. Canada," I 


\section{Up-Dating Lysistrata · 99}

added when the geography didn't seem clear. I felt my usual irritation with Americans who know nothing about us. "Where are you supposed to be?"

"Here I suppose. Since I am." She looked up as the server refilled our cups. When the woman had left, Lysistrata said, "I've told you my name. Does it mean nothing now?"

"The name you mean? Of course," I retorted. "Lysistrata was the Greek who organized all the women to not have sex with the men until they'd stopped fighting. It's a good name to pick - a good heritage." I smiled.

Something in the way she was looking at me - her clothes - not knowing where she was - I pursed my lips. My breath whistled out. Silently, but still a habit I hate. "Oh." I cleared my throat severely. "But Lysistrata was just a character in Aristophanes' play."

She smacked her tongue. "These poets will appropriate anyone! And do whatever they want!"

"You mean Lysistrata really lived?"

"I certainly did."

"You mean, you are Lysistrata? That Lysistrata?"

"Yes. And I've just arrived here." She sipped her coffee, keeping her eyes on me over her cup. I was glad I'd ordered greek and not ceasar salad."

"From where?"

She shrugged. "There is vague when you're here and vice versa." She pronounced it weekay wearsazv as I hadn't heard since high school Latin, and looked surprised at the phrase.

Maybe it was that that made me decide to believe her, maybe it was the doldrums of February, maybe I'm tired of being logical and skeptical. And even if she only believed she was Lysistrata, she might fit my plan. Besides, I liked her.

I took out some money for the bill. Lysistrata held up the bag on her belt. "Let me pay. I seem to have a great number of gold coins."

"Wonderful!" Was this how the universe had chosen to send me the money I'd been affirming my need for? "But save them for later."'

I was wearing an undershirt, duofold turtleneck, sweatshirt and my gore tex. I peeled off the sweatshirt and gave it to her. She pulled it on, disarranging her hair, and I looked at my watch. Twenty minutes before the two-thirty ferry. "Come on." I stood up to begin the Gabriola dash.

We trotted down Commercial, around the corner, into the mall 
department store. Lysistrata was panting but I didn't slow down until we were at socks. Two pairs of woollen ones. I spotted the gumboots. She was small, so a large child's size. No time to try them on; I made her hold up her foot to measure the sole. Fortunately no line-up at the cashier. "Get your money out," I ordered.

Lysistrata rolled her gold coins onto the counter: loonies. The great number was ten. So much for affirmations. I added a five dollar bill, shoved her purchases into the bag, and off we tore again. I made it into the health food and coffee stores but had to pass up the supermarket; the ferry had docked.

We ran to the ticket booth; the last cars were loading; dashed down the ramp. In the lounge we collapsed. Lysistrata sighed and wiped her brow. "Do you always move so fast?"

I gave her her bag and she changed her footwear. Gabriolans are tolerant of attire; no one looked twice at black and red gumboots protruding under her orangey dress now mellowed by my large yellow sweatshirt that had Canadian Marahlands in blue around a black and white loon against green rushes. But when Patsy and later Ron passed through the lounge, I introduced her as Lisa Strata, my old friend from back when. I suppose they thought she was Italian.

Considering she hadn't been around since $500 \mathrm{BCE}$, Lysistrata didn't act too surprised in my car. Maybe you get a crash course before re-entry, who knows.

At home I stoked up the fire and settled her on the couch with a glass of wine before I broached my idea.

"Would you give an address to the Woman's Resource Society for International Women's Day? It'd be an opportunity to tell us how you planned your campaign - "

"Oh, I couldn't possibly," she interrupted. "I'm no good at oratory! I was just a housewife, remember!"

"I know," I soothed. "But it would be very helpful to us. We're in a bit of a crisis situation now."

"But there were many of us. It wasn't just me, you know."

"Then that hasn't changed. There are many of us."

She looked at her still-gumbooted feet on my hassock wiggled her toes, took a sip of wine. "Though I guess I did have the idea first. And I did speak to women in the baths and the marketplace -" She smiled with satisfaction.

"It was an excellent plan and it worked," I encouraged. 
"It doesn't seem to have had the long-lasting effect we hoped for." She looked at me sadly. I glanced at the fire suffused with my usual tangle of sadness, fear, helplessness.

"Yeah, there were the middle ages," I muttered.

"Yes. Lyon, 1492 - " Her tone distant.

The roar of flames, I hover over the heat, watching, smelling the agony of that dissolving body, all I care to remember.

I looked up and she returned my bitter smile. "We were just housewives then too," she whispered.

No wonder this woman was familiar, no wonder I didn't doubt. We'd shared so much, arrest, trial cell, fire - even our names. "Marie?" I whispered.

She nodded. "Why I wasn't keen on coming back again."

I put down my wine glass, lurched up, laughing. She stood too. We hugged. I nearly cried with joy. "In their books 1492's just Columbus now."

"Will you do it?" I asked as we both sat down. "Give a speech?"

"This is rather overwhelming. I'm not sure I'm even speaking in the right language."

"You're doing fine. And I'll help."

"Well -"

"Think about it."

We got dinner ready that night as if we'd done it together a hundred times before, which perhaps we had. Through the preparation, consumption, cleaning up, and then with brandy in front of the fire, I brought Lysistrata up to date. She shook her head, made angry smacking noises and said "oh dear" a lot. By the time I got Suffragettes and hunger strikes she seemed so despairing so I offered my thesis: there are five billion of us on earth now not because of careless breeding, but incarnated to effect some great change. She found it comforting too.

"One of our pressing issues is abortion," I stated. "Hospital boards across the country -"

Lysistrata frowned. "Why are abortions in hospitals? Pregnancy isn't a sickness."

I shrugged in agreement. "It's called a medical procedure."

She sighed. "After what you've been saying nothing should surprise me. The techniques are just getting more subtle."

"Some of them. We're still being beaten, raped and murdered every 
day." I got up to feed the fire and fetch the brandy bottle. "The abortion issue isn't subtle, Lys, it's muddy. The anti-abortionists are taking over hospital boards one by one and ruling that abortions will not be performed in their hospitals. Women are denied access, especially poor women -"

"La plus ça change -?"

"Oui. C'est vrai. Feminists who should be dealing with other problem are spending their energy fighting the same battle over and over. The more we chant outside the board rooms and join the hospital societies and write letters and have demonstrations - by the way, many of these people who call abortion murder would bring back capital punishment if they had the chance - the more we do this the higher the anti-abortionists build their barricades and cheer, 'we've got them really mad, now what else can we do?"' I sighed, rubbed my forehead.

Lysistrata sipped her brandy and stared into the fire. She'd finally taken off her gumboots, lined them up beside her. Now she reached over and caressed them. "We had the same problem in my day. The men were starting some nonsense about the soul entering the fetus through the semen. Why, they were saving their toenail clippings and beard bits and dirty hankerchiefs, saying all their body products were godly! Thank the goddess I died before it got worse! Can you imagine what they'd have saved next?"

I could. I didn't. Instead, I asked "What did you do about abortion?"

"What women have always done. We kept on doing them."

"Without the men knowing?"

"Yes." She pulled her feet up and tucked her dress over them. "It's not a difficult procedure, Sandy." I raised my eyebrow. "You remember."

"I'll wager most women alive today remember, not just the scraping, but the herbs. The gentle herbs and strong herbs. We've always done abortions. And they've been safe as anything to do with pregnancy. Maybe you just need a refresher course."

"It won't work. Midwives are too vulnerable to prosecution for attending births." I had to go to the bathroom.

When I came back Lysistrata was pacing up and down my living room, holding her upper arms, her brandy glass perilously tilted.

"I know what you need to do!" she shouted. "Take abortion back! Let the women do them!" 
I snorted. "Sorry to deflate you. We have. They're called free-standing clinics and they have anti-abortion crusaders chained to the doors harrassing women who go in. Plus we have funding cuts and vandalism."

"Hmm." Now Lysistrata put down her glass and headed to the bathroom. I went outside for more firewood. Snowing again. The third Wednesday in a row.

When we were both back in the living room, Lysistrata said as if thinking aloud, "Sounds like the major problem is this medical procedure business. What if hundreds and thousands of women could do abortions in their homes, quietly, safely, and the women needing them knew where to go by word of mouth?" What if no woman went near a hospital again?"

I laughed. "Wonderful! I love it! You're a genius!" She smiled smugly. I gave her a huge hug, then poured us each another dollop of brandy.

Lys picked up her gumboots and sat down, holding them in her lap as I had done with new shoes as a child. "You gave me these Sandy. Regard my idea as a gift."

"You had your great number of gold coins," I reminded her.

"That gold could be so debased," she sighed. "Maybe the currency should be gumboots."

"But listen, Lys, if no woman goes near a hospital again we won't have any way to make them give us what is our right, control of our own bodies!"

"If it's our right, who can give it to us?"

"You know what I mean -"

"Do you?" Her tone still mild. I was heating up, feeling confused. Confusion is my signal to go away and think, but I'd had too much brandy."

"I mean, fight. Be paid attention to. Have a forum, a public place." I was spitting my words, pacing around, straightening things.

"They paid attention, Sandy. You had a public place. They burned you in it."

"Oh - !" I clenched my fists and teeth so I wouldn't say shut up. I glared. She'd let her hair down,. It fell messily onto my sweatshirt, her arms clutching the boots - she'll need them tomorrow if the snow sticks - I stretched my fingers, breathed in and out deeply. "But this is nearly the twenty-first century. It's not back then." I knew that was lame. 
She nodded. "From what you've said, only the methods have changed."

I collapsed onto the couch. "So you don't think we should fight?"

"Fight to be given a right? Fight for peace? Isn't that a slogan you told me earlier?" I nodded. "We tried it," Lysistrata continued. "Don't think we didn't fight. We hit and yelled and threw things. We killed men that other women loved. Their fathers and mates and sons. All it did was make them learn to fight better. Sounds like they've had centuries of perfecting the skill." She raised one eyebrow and picked up her brandy. I sipped too.

"So we stopped fighting their way. We got organized and went on about our lives. We did everything the same except we didn't allow them to have sex with us."

"Yeah," I interjected, "how many of you got raped? Beaten?"

"Many." Lys's face looked soft, weary. Silent tears leaked from her eyes. I moved next to her, took her hand. "Many. Some didn't survive. My close friend didn't. I was raped, first by my mate and then in the square by others. They tried to get our children, girls and boys, we couldn't let them out of our sight. Sometimes we had to consent so the children would be spared. But eventually the men realized what they were missing - closeness, acceptance, tenderness, intimacy, love - all the things that rape and killing and threats and intimidation can't get them, and finally they laid down their arms. Finally." A small smile through the tears. One bounced on her up-lifted cheek. I wiped it away and squeezed her hand I was still holding.

We sat in silence. I thought, what the history books don't mention.

The fire was very low. I got up and threw on a log. The clock hands were very high. "Maybe we should go to bed," I ventured. Then, "you will stay the night?" We smiled.

I showed her to her room and gave her a towel and tooth-brush. She examined it, puzzled, then tried it on her hair. When I explained, she laughed. "What's wrong with chewing twigs?"

"Too polluted. Besides, tooth brushes uphold the market economy."

I did my bathroom things, said "good-night", staggered through the living room turning out lights, got undressed and crawled into my bed.

The wood stove ticked, cooling down, the clock ticked, going on. I heard the bathroom door open, the light flick off. Exhaustion through 
all of me, but I was so excited. What if no woman went near a hospital again? Wat if we did our own abortions, our own birthings, the way it used to be? Only by counting breaths could I stop waiting for morning. I thought it came much sooner than it did. One of the longer nights. Or dawns. Last of February, the light's changing to spring. I made myself stay in bed until seven.

The snow had warmed to rain, best gum-boot weather. I tiptoed to the kitchen and made coffee, congratulating myself that I'd got it preground. Used the bathroom. Quietly. Put the radio on. Quietly. Started the fire, easing the squeaky door. Poured a cup of coffee. Turned the radio off; I wasn't listening. Thought: I'll take her coffee in bed. Poured it -

The front door opened. In burst Lysistrata, face glowing over my rain poncho, boots covered in mud. "Thought you'd never get up!" she yelled. "Glorious out there, sea lions and eagles, dawn in the rain, my wonderful boots!" I handed her the coffee.

Over scrambled eggs, oranges and toast, I said, "Back to the abortion issue -"

She broke in, all cheer and chatter. "Persistent, aren't you?"

I hmmphed. "Yes. You're making this speech, remember. and this is the topic."

"Oh, I didn't know I was talking about anything, but as I explained, this is AN ISSUE."

"Oh, all these issues! You have so many more words than the last time I saw you in Lyon."

I hmmphed inwardly. "In the night I was thinking that then, in Lyon, we were quietly minding our own business. We weren't fighting. We were doing abortions, remember we'd go to the fields together and we knew all the herbs, what to give a woman in the first month, the second, none of this trimester stuff, and we healed other things, we healed too."

I started to sob. "Even abortion's healing, it's healing the rapes of wars, healing mistakes of the world!"

Lys knelt and put her arms around me. A meadow, a forest, basket on my arm, looking for - can see the plants, their names -?

I got a tissue, blew and mopped. Lysistrata say down again.

"Lys, I'm scared. We were just minding our own business then, gathering herbs, looking after others, and they came and got us and burned us." 
She touched my arm. "I was scared when I arrived on the street yesterday. Wherever the other of here is, it isn't so scary as here. I'd forgotten fear."

"I try to." I sat up and shovelled in mouthfuls of cold egg and toast.

She picked up her cup. "You're right, Sandy. We were just doing what we'd always done, and they burned us. There's much power in healing. They didn't like our power." Her tone centered, contemplative. "Back in Greece and here, we were - are actively challenging. Is it worse to be killed for doing something than for doing nothing?"

"That's what I meant last night! We should be fighting!"

Lys poured herself more coffee. "No, Sandy. Fight is the wrong word. To resist is wrong also. It's all part of the same thing. If one doesn't fight, then the other has no one to fight."

"Then they just win by default."

She shrugged. "They have already won. In their terms, they have the power."

"But they can make things much worse," I persisted. "We'll be back to the witch hunts. You and I have already burned. Along with millions of others!"

"Do you want to fight? Is that what you want?"

I thought for a minute. "No. I want to be acknowledged. Seen. Not just accepted, but appreciated. Able to walk free without fear. And I guess I want acknowledgement of having been burned at the stake. That was not nice."

Lysistrata laughed until she choked. I thumped her back. "Not nice? Most definitely it was not nice! What do you mean, nice?"

"My generations heritage," I sneered. "Nice girls don't. It's hard to unlearn nice."

I cleared the table, poured more coffee and moved to the living room. Outside, grey mist melded the grey-green trees and remnants of snow. Lysistrata put another log on the fire. At least she'd left her now muddy gumboots by the door. She closed the stove, brushed her hands together, stood up. "What is it you really want me to say in this speech?"

"Whatever you want," I replied automatically. She made a face. "What you have been saying and more of it. Another perspective is so useful. We're all a littled mired in our own."

"I only have one thing to say. Go on strike."

"But it has to be tied to the issues." Ooh, was I whining? 


\section{Up-Dating Lysistrata · 107}

She sighed pointedly. "With the abortion issue, you do nothing more publicly."

"But in Lys - in your play, you went on strike in a public place!" I blurted.

"Nonsense! Do you think all us women could have marched to the Acropolis without the men knowing? Without being picked off before we got there? That Aristophanes, the acropolis was cheap staging for him! We worked in our homes and the marketplace!" She was pacing back and forth, arms crossed, her too-large socks flapping at the toes. I sat down, remembered my coffee, sipped.

"Some of you learn to do abortions, Sandy, surely there is a woman who will teach you -" she erased that with her hand - "remind you. Those of you who know know remind others, and they remind others and so on. From what you've said your world sounds like it's at war. Unless you want to take up swords and catapults, fight with their weapons, this is the only way to do what we have always done. What were you telling me last night about the underground? Going underground? Surely Demeter and Persephone have not been ignored the way I have?"

She was looking at me, so I shook my head in acknowledgement. Lys snorted before continuing. "There's nothing mysterious about abortion. You make it sound as if your rulers have turned it into an Eleusian mystery. Well, Sandy, we're the priestesses. We're in charge of the ceremonies, if nor our own bodies all the time. Put out the word which houses are safe. The women who need them will know. This is how women have worked for thousands of years."

"Oh yes, but - " I waved my hand vaguely. Confused again. Wanted to say, but you don't really understand what it's like now.

Lysistrata rubbed her hands briskly. "Now what other issues are there?" I just looked at her. "Come, on, Come on, what other issues?"

She reminded me of my grade five teacher. I'd rarely had the answer then. Now I tried. "Um. What you said about fighting or notfighting. The underground. Like whether women should go into business or politics or sports, the men's arenas." I sat up and made an effort to stop sounding like my ten year old self. "Some women say none of us should work within an existing system, that they're all patriarchal. Other women think that by going into politics and theology and the stock market, they can effect change. But some perceive these women as tokens and think everything's fine for women. And 
some women who've been successful in business or politics say if I can make it, any woman can. Overall, nothing really changes for women. We still get shoved into tight skirts and high heels, forced to live with pornography or go on the streets to support ourselves. Older, single women, like you and me, have the least money. Or if things do change for women, they're only the things that serve the men in power."

"Always thus. Always thus." Lys was up and striding again. "Is it not better to have women in the men's rooms that to have them locked out?"

"Who'd want to be in them?"

"That's not the point, Sandy. In my day - my Grecian day - we were kept out of anything the men were doing. Much better to see for yourself what's going on than to only know what they choose to report. It's called spying."

I laughed. "I've never thought of it that way."

"Well, start to," she said. "Now another issue?" She paused in her pacing long enough to finish her coffee.

I hunched forward, my mind a thruway at rush hour, green issues, red issues, overtaking and colliding issues - I pulled out one. "We have this thing in the universities called Women's Studies, just had it for a few years, now there are men taking it -"

"Might not be bad, " if they don't take it over."

"- and teaching it - "

"Aha, they have! So you can't spy there any more!"

I put my hands over my face. "Lysistrata, be serious! Women's Studies teaches women about women's history. It isn't spying."

"Isn't it training spies?"

My head was shaking back and forth. My hands were tearing at the roots of my hair. I looked up. Lys was smiling seriously. Or seriously smiling. I had to grin. "Well, maybe. But it doesn't feel like that, feels like they've taken over our arena."

"Of course they have. Aristophanes' staging the play in the acropolis was a codifying of the takeover. The acropolis was first for goddesses."

"So you don't see any point in fighting this?"

"No. Do you?"

"Yes, for god's sake! They're doing it bloody well once again!" I was on my feet. 


\section{Up-Dating Lysistrata 109}

"Since when was blood a swear word?"

"Since Jesus, I suppose. No, since men discovered they had something to do with procreation and wanted all the credit."

You didn't tell me last night that they've even taken over our bleeding."

I didn't keep the surprise out of my voice. "You knew that in Lyon. Wasn't one of the reasons we were burned, we bled like they wanted their icons to?"

"Oh right," said Lys. "These silly men, trying to bleed all over the place. Spilling blood." She sat down. I fed the fire, looked out at the mist. Lifting. I couldn't take much more of this discussion, time to go for a walk.

She asked slowly, perhaps rhetorically, "Did we once actually know a way to live in which were all happy?"

"I think so," I told the window. "I have flashes of that." I spun around. "I do know it's possible. Women and men living happily together, not hurting each other."

"Oh good." Her tone shrunken. "Glad you do. I'm not sure."

"What should we do about women's studies?" I wanted her pacing her track again.

"You're the priestesses. Teach the young yourselves."

"That's separatism!" Out of my mouth before I could think. "What do you mean?" I tried to cover up.

"Why go to the men asking for your right again? It is your right to teach the young. If the men don't want you to do it - and I told you I define this period as wartime - then do it yourselves." She looked up at me, still standing by the window. "I think that's all I have to say on your issues, Sandy. I want to put my gumboots on."

I spent last week walking with Lys. Once I showed her the binoculars, it was tedious. She took them everywhere. A walk consisted of stopping, putting the binocs to her eyes and mumbling. I studied a lot of waves. I taught her to drive my car, she has a mechanical inclination, and showed her the petrogylphs. She didn't know any more about them than I do. Today, however, she announced that she'd said everything she had to say on any issue and if I didn't mind, she'd stay home. Oh, I said I minded a great deal, and we had a nasty fight, but she was not swayed. That's why I'm presenting this. She did say she'd pick me up at the ferry. 